\title{
A Phenolic Acid Decarboxylase-Based All-Enzyme Hydrogel for Flow Reactor Technology
}

\author{
Esther Mittmann ${ }^{1} \mathbb{1}$, Sabrina Gallus ${ }^{1}$, Patrick Bitterwolf ${ }^{1}$, Claude Oelschlaeger ${ }^{2}$, \\ Norbert Willenbacher ${ }^{2}$, Christof M. Niemeyer ${ }^{1}\left[\right.$ and Kersten S. Rabe ${ }^{1, * \mathbb{C}}$ \\ 1 Institute for Biological Interfaces (IBG-1), Karlsruhe Institute of Technology (KIT), 76187 Karlsruhe, \\ Germany; esther.mittmann@kit.edu (E.M.); sabrina.gallus@kit.edu (S.G.); patrick.bitterwolf@kit.edu (P.B.); \\ niemeyer@kit.edu (C.M.N.) \\ 2 Institute for Mechanical Process Engineering and Mechanics (MVM), Karlsruhe Institute of Technology (KIT), \\ 76187 Karlsruhe, Germany; claude.oelschlaeger@kit.edu (C.O.); norbert.willenbacher@kit.edu (N.W.) \\ * Correspondence: kersten.rabe@kit.edu; Tel.: +49-721-608-24469
}

Received: 18 October 2019; Accepted: 18 November 2019; Published: 20 November 2019

\begin{abstract}
Carrier-free enzyme immobilization techniques are an important development in the field of efficient and streamlined continuous synthetic processes using microreactors. Here, the use of monolithic, self-assembling all-enzyme hydrogels is expanded to phenolic acid decarboxylases. This provides access to the continuous flow production of $p$-hydroxystyrene from $p$-coumaric acid for more than $10 \mathrm{~h}$ with conversions $\geq 98 \%$ and space time yields of $57.7 \mathrm{~g} \cdot(\mathrm{d} \cdot \mathrm{L})^{-1}$. Furthermore, modulation of the degree of crosslinking in the hydrogels resulted in a defined variation of the rheological behavior in terms of elasticity and mesh size of the corresponding materials. This work is addressing the demand of sustainable strategies for defunctionalization of renewable feedstocks.
\end{abstract}

Keywords: biocatalysis; phenolic acid decarboxylase; hydrogel; enzyme immobilization; SpyCatcher/SpyTag; microreactor

\section{Introduction}

The current transformation of the chemical industry calls for a constant intensification of the use of biomass as feedstock for the sustainable synthesis of fine chemicals. However, the high complexity of this renewable raw material and especially the high mass fraction of oxygen in comparison to fossil carbon resources is limiting its widespread utilization. Decarboxylation is an important method for defunctionalization, which can be employed to alleviate these impediments [1-5].

In order to add value to ubiquitously available bio-derived phenolic acids [6-11], and to provide alternatives to chemical methods often relying on transition metal catalysis $[2,10,12]$, phenolic acid decarboxylases (PADs) offer an elegant enzymatic route to catalyse the elimination of carbon dioxide from hydroxyphenacrylic acids [13-15]. The resulting styrene derivatives are of great industrial relevance since the terminal alkene provides a versatile handle for further chemical functionalization or polymerization reactions [16-18]. In contrast to other (de)carboxylases, several PADs found in bacteria [19-22] and plants [23] act on an acid-base mechanism via a quinone methide intermediate [24] and do not require a cofactor, therefore eliminating the need of a laborious and expensive cofactor regeneration system $[25,26]$.

The versatility of PADs has been demonstrated by integration of the decarboxylation reaction into biocatalytic [6,27] and chemical [28-30] reaction cascades. However, limitations can arise due to the product inhibition $[28,29]$ frequently observed for this class of enzymes. The transfer of the process from batch stirred tank reactors to fluidic, micro- and macrostructured reactors can provide a viable 
solution, as the convective product removal can avoid the accumulation of high and adverse product concentrations [31]. Therefore, much effort is currently devoted to the development of continuous flow reactors employing immobilized enzymes [32-36]. In general, such reactors can be prepared by anchoring the enzyme of interest on the reactor surface using a variety of chemical methods or else by entrapment or crosslinking of the enzymes [34,37,38]. Immobilizing the enzymes on the planar surfaces of a reactor wall can result in a single monolayer, limiting the catalytic performance. Here, employing immobilization strategies which result in three-dimensional structures, can lead to a significant increase of the enzymatic activity per reactor volume. This approach can be facilitated with so-called crosslinked enzyme aggregates or crystals (CLEAs or CLECs) [39-43]. Another advantage of this strategy is the minimization of carrier materials, so that only a small volume of the valuable reactor space is needed for supporting structures. However, since the crosslinking process usually relies on non-specific chemical crosslinkers, this method can lead to the inactivation of enzymes.

We have recently demonstrated the construction of self-assembling all-enzyme hydrogels constructed from ketoreductases and glucose dehydrogenases, which were genetically fused with either the SpyTag (ST) peptide or the SpyCatcher (SC) protein, respectively [44-46]. This highly efficient autocatalytic bioconjugation system is based on the rapid formation of a covalent isopeptide bond through the SpyTag-SpyCatcher complex that occurs under physiological conditions [47-50]. To render the all-enzyme hydrogel immobilization strategy applicable to a broader range of biocatalysts, we here report, for the first time, on the use of recombinant variants of a highly active homodimeric PAD (molecular weight of a monomer $20 \mathrm{kDa}$ ) obtained from Enterobacter sp. [51]. By creating SC- and ST-tagged PAD variants we demonstrate the fabrication of all-enzyme hydrogels. The functionality of the novel biocatalytic materials is demonstrated by the continuous production of p-hydroxystyrene in a microfluidic flow reactor (Figure 1).

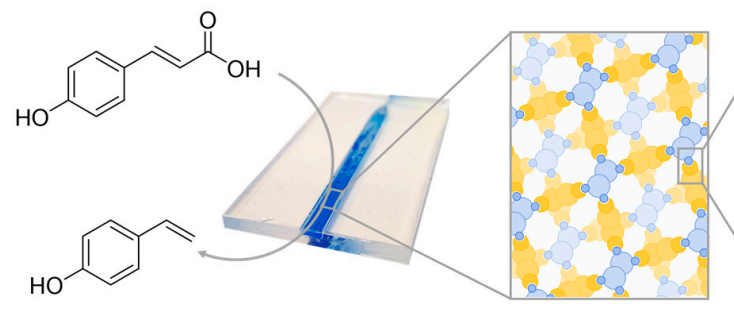

(a) (b)

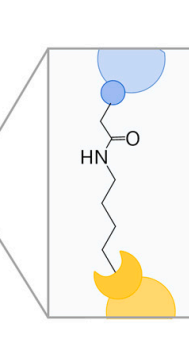

(c)

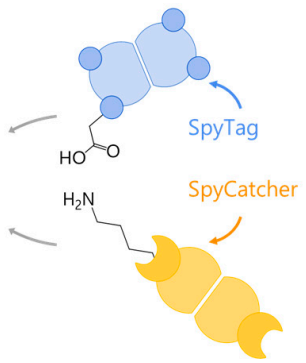

(d)

Figure 1. (a) Continuous synthesis of substituted styrenes from readily available bio-derived phenolic acids through biocatalytic decarboxylation, as exemplified here for p-hydroxystyrene, is achieved by implementation of a microreactor (b). This reactor is filled with an all-enzyme hydrogel (c) comprised of the dimeric Phenolic Acid Decarboxylase (PAD), crosslinked via isopeptide bonds spontaneously generated through genetically fused SpyTag/SpyCatcher complexes (d). Note that the protein hydrogel loaded into the micro reactor $(\mathbf{b})$ is stained with coomassie brilliant blue.

\section{Materials and Methods}

All chemicals were purchased from Sigma Aldrich (St. Louis, MI, USA) or VWR (Radnor, PA, USA) if not stated otherwise.

\subsection{Synthesis of p-Hydroxystyrene Via Wittig Reaction}

For calibration curves and as positive control, $p$-hydroxystyrene was synthesized as described previously (Scheme 1) [52]. In brief, potassium tert-butoxide ( $\geq 98 \%, 2.81 \mathrm{~g} ; 25 \mathrm{mmol})$ was added to a mixture of methyl triphenylphosphonium bromide ( $\geq 98 \%, 5.36 \mathrm{~g} ; 15 \mathrm{mmol})$ in anhydrous tetrahydrofurane THF (ACS grade, $20 \mathrm{~mL}$ ) under argon atmosphere. The mixture was stirred for $10 \mathrm{~min}$ at ambient temperature. Subsequently $p$-hydroxybenzaldehyde ( $\geq 98 \%, 1.52 \mathrm{~g}$; $10 \mathrm{mmol})$ dissolved in 
THF (10 mL) was added dropwise. The reaction was stirred for $4 \mathrm{~h}$ and the product formation was monitored by thin layer chromatography (TLC). After quenching of the reaction mixture with saturated $\mathrm{NH}_{4} \mathrm{Cl}$ solution and the removal of THF under reduced pressure, the crude product was extracted with $\mathrm{CH}_{2} \mathrm{Cl}_{2}$ (analytical grade). The organic layer was washed with a saturated $\mathrm{NaCl}$ solution, dried over anhydrous $\mathrm{Na}_{2} \mathrm{SO}_{4}$, and after filtration and evaporation of the solvent, purified by chromatography column $\left(\mathrm{SiO}_{2}, 5 \%\right.$ ethyl acetate in $n$-hexane) to give pure $p$-hydroxystyrene, $834.5 \mathrm{mg}(6.945 \mathrm{mmol})$ in a $69.5 \%$ yield as white crystals. $R_{\mathrm{f}}=0.44$ (16\% ethyl acetate in $n$-hexane). The nuclear magnetic resonance (NMR) spectra matched with literature data.

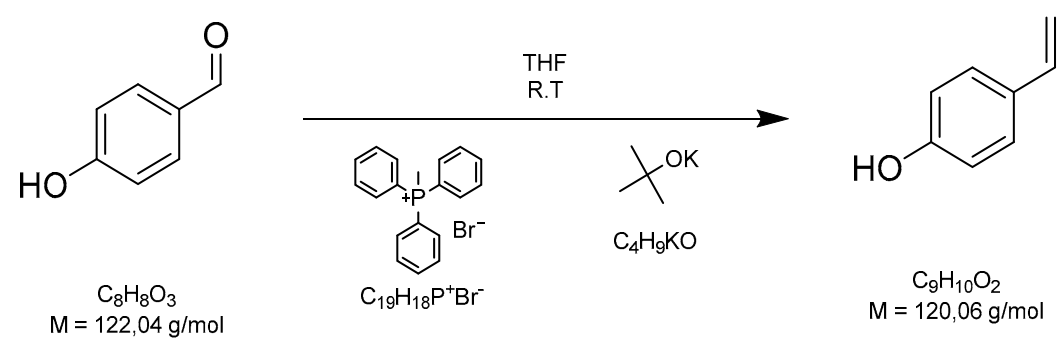

Scheme 1. Synthesis of $p$-hydroxystyrene.

\subsection{Plasmid Construction}

Plasmid construction was carried out using the isothermal recombination as described by Gibson et al. utilizing oligonucleotide primers with 20-30 bp homologous overlaps [53]. The products of the in vitro recombination were then incubated for $1 \mathrm{~h}$ at $37^{\circ} \mathrm{C}$ with DpnI (New England Bioloabs, Beverly, MA, USA) to ensure the sample did not contain any methylated DNA templates from previous polymerase chain reactions. The purification of dissolved plasmids was carried out using the ZR Plasmid Miniprep-Classic (Zymo Research, Freiburg, Germany). Sequences were verified by commercial sequencing (LGC Genomics, Berlin, Germany). The sequences of the primers can be found in Table 1. pET_PAD-His was used as a template for further cloning steps [30].

Table 1. Primers used in this study.

\begin{tabular}{ll}
\hline Primer & DNA-Sequence \\
\hline EM01 & GGTCATCATCACCATCATCATTAAGATCC \\
\hline EM02 & GCTACCACCACCACCTTTCAGATTATC \\
\hline EM03 & CCGGATAATCTGAAAGGTGGTGGTGGTAGCGTTGATACCCTGAGCGGTCTGAG \\
\hline EM04 & CGGATCTTAATGATGATGGTGATGATGACCAATATGTGCATCACCTTTGGTTGCTTTACC \\
\hline EM05 & TGGTTGATGCATATAAACCGACCAAAGGTCATCATCACCATCATCATTAAGATCC \\
\hline EM06 & CGGTTTATATGCATCAACCATAACAATATGTGCGCTACCACCACCACCTTTCAGATTATC \\
\hline EM07 & CACAATTCCCCTATAGTGAGTCGTATTAATTTC \\
\hline EM08 & GTGAAAGCATCTATAAAATCAGCTGGACC \\
\hline
\end{tabular}

pET_PAD-SC-His: The backbone encoding for a N-terminal PAD and C-terminal 6× His-Tag separated by a glycine spacer was amplified using primers EM01 and EM02 with pET_PAD-His as the template. This backbone was then recombined with a SC encoding insert, which had been generated by polymerase chain reaction (PCR) using the primers EM03 and EM04 with pTF16_Lpp-OmpA-SC as the template [48]. pET_PAD-ST-His: The C-terminal ST sequence were inserted into plasmid pET_PAD-His by PCR using the primers EM05 and EM06. pET_ST-PAD-ST-His: The plasmid pET_PAD-ST-His was amplified by PCR using the primers EM07 and EM08 resulting in a linearized plasmid backbone which was then complemented to the full-length PAD with a DNA-fragment 
containing an additional N-terminal ST-GGGGS and matching overlaps (synthesized via "GeneArt Gene Synthesis" by ThermoFisher, Waltham, MA, USA) using Gibson assembly, as described above.

\subsection{Gene Expression and Protein Production}

Chemically competent Escherichia coli BL21 (DE3) were transformed with the corresponding expression vector. E. coli cells containing the expression vector were selected overnight at $37^{\circ} \mathrm{C}$ on lysogeny broth (LB)/agar plates containing $100 \mu \mathrm{g} / \mathrm{mL}$ ampicillin. For expression, a single colony was transferred to a suitable volume of LB medium containing $100 \mu \mathrm{g} / \mathrm{mL}$ ampicillin and the culture was incubated overnight at $37^{\circ} \mathrm{C}$ and $180 \mathrm{rpm}$ in a shaking incubator. The overnight culture was then used to inoculate a 20 times larger volume of $25^{\circ} \mathrm{C}$ warm ampicillin containing LB medium. This culture was then incubated for approximately $1.5-2 \mathrm{~h}$ up to an $\mathrm{OD}_{600}$ of $0.6-0.9$ at $37^{\circ} \mathrm{C}$ and $180 \mathrm{rpm}$. After reaching the appropriate cell density, the culture was cooled down to $25^{\circ} \mathrm{C}$ for at least $15 \mathrm{~min}$ and subsequently induced with isopropyl $\beta$-D-1-thiogalactopyranoside (IPTG) to a final concentration of $0.5 \mathrm{mM}$. The induced culture was then incubated overnight at $25^{\circ} \mathrm{C}$ and then harvested by centrifugation $\left(10,000 \times g, 10 \mathrm{~min}, 4{ }^{\circ} \mathrm{C}\right)$. The cells were then resuspended in cold sodium phosphate buffer containing $10 \mathrm{mM}$ imidazole (NPI 10; $50 \mathrm{mM}$ $\mathrm{NaH}_{2} \mathrm{PO}_{4}, 500 \mathrm{mM} \mathrm{NaCl}, 10 \mathrm{mM}$ Imidazole, $\mathrm{pH}$ 8) and frozen at $-80{ }^{\circ} \mathrm{C}$.

\subsection{Protein Purification}

The cell pellets were thawed at $25^{\circ} \mathrm{C}$ in a water bath and then incubated with DNaseI and lysozyme for $30 \mathrm{~min}$ at $25^{\circ} \mathrm{C}$. Further cell disruption was then carried out using ultrasonification. The lysate was subsequently centrifuged for $1 \mathrm{~h}$ at $45,000 \mathrm{rcf}$ and $4{ }^{\circ} \mathrm{C}$. The pellet was discarded and the supernatant sterile-filtered through a $0.45 \mu \mathrm{m}$ Durapore PVDF membrane with Steriflip ${ }^{\circledR}$ Filter Units (Merck, Darmstadt, Germany). For protein purification, the cleared lysate was loaded on $2 \times 5 \mathrm{~mL} \mathrm{His}_{60} \mathrm{Ni}$ Superflow Cartridge (Clontech, Palo Alto, CA, USA) mounted on an Äkta Pure liquid chromatography system (GE Healthcare, Freiburg, Germany). The purification was carried out with NPI 10 as running buffer and sodium phosphate buffer containing $500 \mathrm{mM}$ imidazole (NPI 500;50 mM NaH $\mathrm{PO}_{4}, 500 \mathrm{mM} \mathrm{NaCl}, 500 \mathrm{mM}$ Imidazole, pH 8) as elution buffer. After applying the lysate onto the column, the column was washed with $2 \%$ NPI 500 and the protein was eluted using a linear gradient ( $2 \%$ to $100 \%$ NPI 500 ). The column outflow was collected in $900 \mu \mathrm{L}$ fractions and protein containing fractions (detected at $280 \mathrm{~nm}$ ) were pooled. Subsequently, the buffer was exchanged to phosphate buffered saline (PBS) using Vivaspin 20, 5000 MWCO concentrators (Sartorius, Göttingen, Germany).

\subsection{Sodium dodecyl sulfate-polyacrylamide gel electrophoresis (SDS-PAGE) Analysis}

Samples were mixed with $4 \times$ SDS-PAGE loading buffer (200 mM Tris-Cl, pH 6.8, 400 mM DTT, 8\% SDS, $0.4 \%$ bromophenol blue, $40 \%$ glycerol), boiled at $95{ }^{\circ} \mathrm{C}$ for $10 \mathrm{~min}$ and loaded onto a $1 \mathrm{~mm}$ thick SDS-PAGE gel containing $16 \%$ acrylamide. The gels were run at $100 \mathrm{~V}$ and stained with coomassie Brilliant Blue G-250. PageRuler (Plus) Prestained (Thermo Fisher Scientific) was used as molecular weight reference marker.

\subsection{Determination of Decarboxylase Activity}

Fifty $\mu \mathrm{L}$ of an enzyme solution in $\mathrm{KP}_{\mathrm{i}}$ buffer $\left(25 \mathrm{mM} \mathrm{KP} \mathrm{i}_{\mathrm{i}}, \mathrm{pH}\right.$ 6) were transferred in an ultraviolet (UV) transparent 96 well microtiter plate and $150 \mu \mathrm{L}$ of $p$-coumaric acid to a final concentration of $1 \mathrm{mM}$ in $\mathrm{KP}_{\mathrm{i}}$ buffer were added. The consumption of $p$-coumaric acid was recorded at $294 \mathrm{~nm}$ using a Synergy MX microplate reader (BioTek, Winooski, VT, USA) over a period of $10 \mathrm{~min}$ at $25^{\circ} \mathrm{C}$. The activity was determined by calculating the slope in the linear range of the decrease of the absorption intensity (OD/min).

\subsection{Hydrogel Prepration}

Protein solutions of PAD-SC and PAD-ST/ST-PAD-ST were diluted in $\mathrm{KP}_{\mathrm{i}}$ buffer to a final total protein concentration of $1 \mathrm{mM}$ in $20 \mu \mathrm{L}$ for analysis of ST/SC complex formation. For microrheology 
measurements a total volume of $200 \mu \mathrm{L}$ was used and $0.2 \mathrm{mg} / \mathrm{mL}$ "dragon" green fluorescent polystyrene microspheres (200 nm diameter; Bangs Laboratories, Fishers, IN, US) were added. Polymerization was carried out for $1 \mathrm{~h}$ at $30^{\circ} \mathrm{C}, 1000 \mathrm{rpm}$ in a thermoshaker. Subsequently, the buffer was evaporated under constant centrifugation at $2200 \times g$ for overnight at $30^{\circ} \mathrm{C}$.

\subsection{Microrheology Measurements}

Prior to multiple particle tracking (MPT)-analysis, the dried hydrogel samples were swollen by adding $25 \mu \mathrm{L} \mathrm{KP}$ i buffer for $30 \mathrm{~min}$ under continuous shaking at $25^{\circ} \mathrm{C}, 500 \mathrm{rpm}$. To perform MPT experiments, we used green fluorescent polystyrene microspheres of $200 \mathrm{~nm}$ diameter as tracer particles. Images of the beads were recorded onto a personal computer via a sCMOS camera Zyla $X$ (Andor Technology, $50 \mathrm{f} / \mathrm{s}$, Belfast, Northern Ireland) mounted on an inverted fluorescence microscope (Axio Observer D1, Zeiss, Kohen, Germany) equipped with a Fluar 100×, N.A. 1.3, oil-immersion lens. Movies of more than 100 fluctuating microspheres were analysed using the software Image Processing System (iPS, Visiometrics, Terrassa, Spain) and a self-written Matlab code, based on the widely used Crocker and Grier tracking algorithm [54].

To characterize sample heterogeneities, we examined the distribution of mean square displacements (MSDs), known as Van Hove correlation function [55] and calculated the non-Gaussian parameter $\alpha$ [56]:

$$
\alpha=\frac{\left\langle x^{4}(\tau)\right\rangle}{3\left\langle x^{2}(\tau)\right\rangle^{2}}-1
$$

where $x$ is the distance of particle center of mass along the $x$ coordinate. This quantity is zero for a Gaussian distribution which is expected for a homogeneous and uniform sample, while higher $\alpha$ values reflect the presence of spatial heterogeneities.

\subsection{High Performance Liquid Chromatography (HPLC) Analysis}

All high performance liquid chromatography (HPLC) analyses were performed on an Agilent Technologies (Palo Alto, CA, USA) 1260 Bioinert Series with autosampler and diode array detector (DAD). $P$-hydroxystyrene and $p$-coumaric acid were detected and quantified by reverse phase HPLC using an Eclipse XDB C18 column (5 $\mu \mathrm{m}$, Agilent) with a precolumn of the same material. The separation was realized at $10{ }^{\circ} \mathrm{C}$ with an isocratic mobile phase consisting of $60 \%$ acetonitrile and $40 \%$ dd ${ }_{2} \mathrm{O}$ with $0.1 \%$ (v/v) trifluoroacetic acid. The flow rate was $1.5 \mathrm{~mL} / \mathrm{min}$. Absorption was detected simultaneously at 260, 275 and $370 \mathrm{~nm}$ and a suitable wavelength for calibration and evaluation was chosen for each substrate. For calibration, dilutions of $p$-hydroxystyrene and $p$-coumaric acid in the range of $0.5-5 \mathrm{mM}$ were prepared. For measurements, $150 \mu \mathrm{L}$ of each sample were diluted with $150 \mu \mathrm{L}$ acetonitrile additionally containing 40 $\mu \mathrm{M} p$-hydroxyazobenzene as internal standard and $250 \mathrm{mM} \mathrm{HCl}$ prior to application.

\subsection{Microfluidic Setup and Analysis of the Hydrogels Under Continuous Flow}

The microfluidic reactor was prepared as previously described [44]. The upper part containing the reaction channel was prepared by pouring of polydimethylsiloxane (PDMS) (Sylgard 184, Dow Corning, Midland, MI, USA) over molds to generate replicas. The channel architecture featured a straight channel which was $3 \mathrm{~mm}$ wide, $1 \mathrm{~mm}$ high and $54 \mathrm{~mm}$ long and a total volume of $150 \mu \mathrm{L}$. To serve as spacers for later fluidic connectors, cannulas (Sterican, B. Braun Melsungen AG, Melsungen, Germany) were integrated in the brass replica molds. The PDMS was cured at $60{ }^{\circ} \mathrm{C}$ for at least $3 \mathrm{~h}$.

The microreactor was typically mounted inside an incubator (set to $30^{\circ} \mathrm{C}$ ), filled with $150 \mu \mathrm{L} 1 \mathrm{mM}$ protein solution (PAD-SC/ST-PAD-ST 2:1) and incubated for $60 \mathrm{~min}$. The PDMS chips were then sealed with a polyolefin foil (HJ-BIOANALYTIK GmbH, Erkelenz, Germany). Low pressure syringe pumps (neMESYS 290N) equipped with $10 \mathrm{~mL}$ syringes were connected to a manual switching valve that was connected to the reactor for perfusion of reaction media at a flowrate of $10 \mu \mathrm{L} / \mathrm{min}$. The syringes were filled with $10 \mathrm{~mL}$ substrate solution containing $5 \mathrm{mM}$ of $p$-coumaric acid in $\mathrm{KP}_{\mathrm{i}}$ buffer and $0.01 \%$ 
(v/v) sodium azide to avoid fouling. The reactor outflow was connected to the Compact Positioning System rotAXYS360 (CETONI, Korbussen, Germany) to allow for automatic fractioning into 96-well plates, previously loaded with $150 \mu \mathrm{L} 250 \mathrm{mM} \mathrm{HCl}$ in acetonitrile to stop all enzymatic reactions and $40 \mu \mathrm{M} p$-hydroxyazobenzene used as standard for internal calibration. The flow was generated using a CETONI neMESYS Base module. Syringe pump and positioning system were controlled by the QmixElements-Software. The flow modules were connected via tubing (inlets: silicone Tygon tubing R3603, ID = $1.6 \mathrm{~mm}$, Saint-Gobain, Cavaillon, France; outlets: conventional PTFE tubing, ID = $0.5 \mathrm{~mm}$ ).

\section{Results and Discussion}

In order to develop a PAD-based all-enzyme hydrogel, we initially generated expression plasmids for PAD variants that were genetically fused with polypeptide domains of SC or ST. Overexpression in E. coli and purification via an additional $6 \times$ His-Tag allowed to obtain the biocatalytically active recombinant proteins in near homogeneous purity, as judged from SDS-PAGE analysis (Figure 2a). This high purity allowed us to later produce materials with precisely defined properties. All variants expressed with very high expression yields $\geq 100 \mathrm{mg} / \mathrm{L}$ culture in a non-optimized process. To assess the catalytic performance of these PAD species, a first benchmark test was performed following the decrease of substrate by monitoring its absorption at $294 \mathrm{~nm}$. The results in Figure $2 \mathrm{~b}$ show the direct comparison of the activity of the various enzyme variants to convert the model substrate $p$-coumaric acid. It is clearly evident that all variants show comparable activities, however, the addition of one or two tags slightly decreased the activity as compared to the enzyme without an additional tag (dark blue bar, Figure 2b).

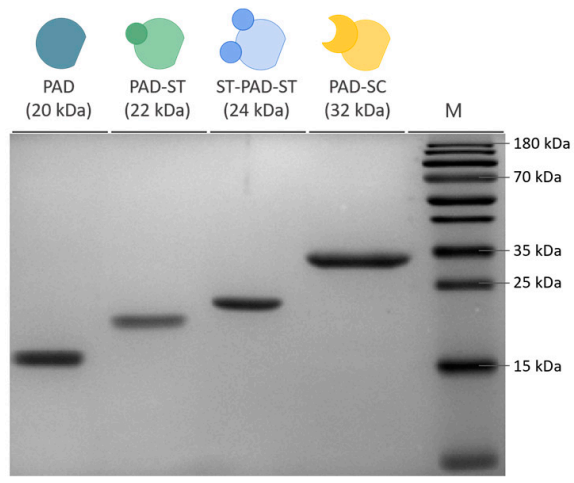

(a)

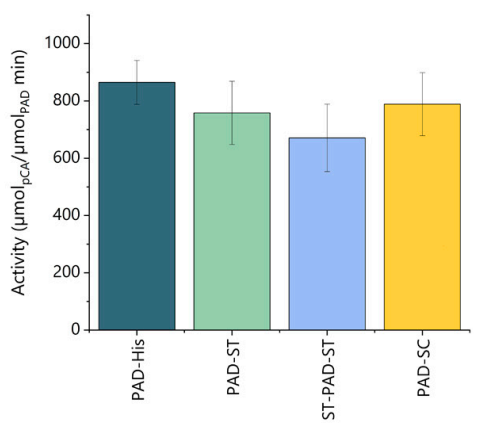

(b)

Figure 2. Variants of phenolic acid decarboxylase (PAD) from Enterobacter sp. containing either one or two SpyTag (ST) or one SpyCatcher (SC) were expressed in Escherichia coli, purified and tested for their activity towards $p$-coumaric acid. Note that all proteins carry a C-terminal $6 \times$ His-Tag. (a) Denaturing $16 \%$ SDS-PAGE analysis of the purified PAD constructs. The PAD variants used here are homodimers in their native form. Lane 1: PAD (20 kDa), Lane 2: PAD-ST (22 kDa); Lane 3: ST-PAD-ST (24 kDa); Lane 4: PAD-SC (32 kDa); Lane 5: PageRuler Prestained Protein Ladder (Thermo Scientific). (b) Enzymatic activity at $25{ }^{\circ} \mathrm{C}$ in $\mu \mathrm{mol}_{p \mathrm{CA}} /\left(\mu \mathrm{mol}_{\mathrm{PAD}} \mathrm{min}\right)$ of the four differently tagged PAD variants against $1 \mathrm{mM}$ $p$-coumaric acid ( $p \mathrm{CA})$ as substrate, determined by an absorbance based depletion assay.

Since the PAD enzyme naturally occurs as a homodimer we generated variants with one (PAD-ST) or two SpyTags (ST-PAD-ST) in order to study self-assembly properties with the complementary partner containing one SpyCatcher (PAD-SC) per monomeric subunit. This strategy should allow us to vary the degree of crosslinking and thus mesh size of the hydrogel by adjusting the stoichiometric molar ratios of the different enzyme variants, as illustrated in Figure 3a. Several types of PAD-hydrogels (H1-H4, Figure 3) were produced. For type H1 hydrogel, only PAD-SC and ST-PAD-ST were mixed in a 2:1 molar ratio, which should result in the highest possible degree of crosslinking. For type $\mathrm{H} 2$, prepared with a ratio of 4:2:1 of PAD-SC:PAD-ST:ST-PAD-ST, a lower degree of crosslinking was 
expected. Likewise, type H3, formed from a molar ratio of 6:4:1 of PAD-SC:PAD-ST:ST-PAD-ST, should display a further reduced degree of crosslinking. In type H4, where no double-tagged ST-PAD-ST was used and the PAD-SC:PAD-ST ratio was adjusted to 1:1, linear chains of crosslinked proteins should be formed without any branching points.

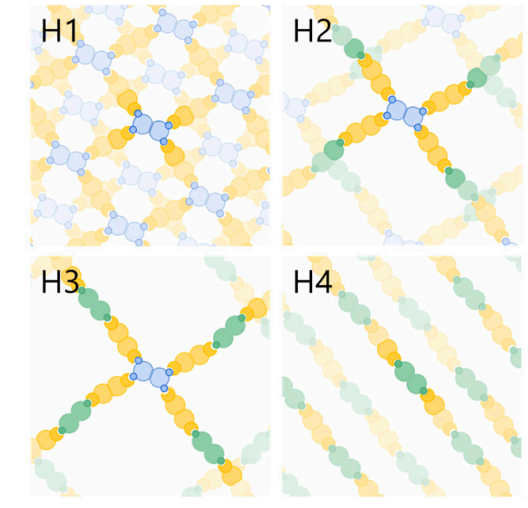

(a)

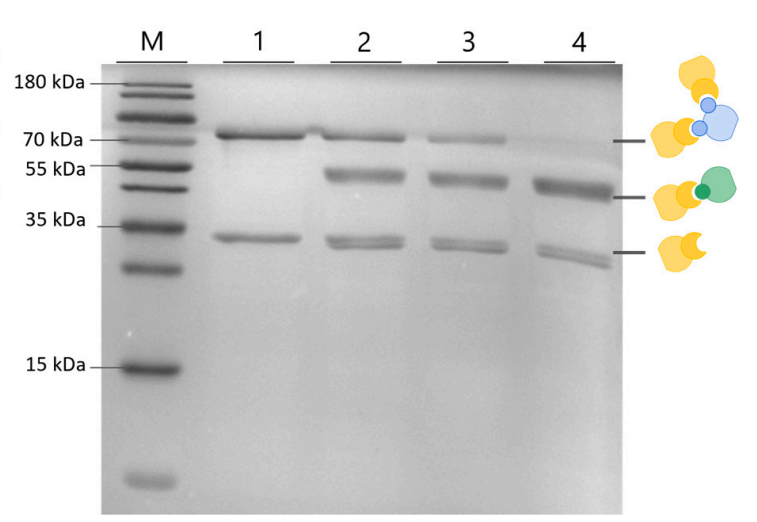

(b)

Figure 3. (a) Different types of PAD-Hydrogels (H1-H4) with different degrees of crosslinking can be prepared by using different stoichiometries of the SC/ST-tagged PAD variants. The various different hydrogels are depicted here as simplified and idealized 2D-representations with the individual building blocks approximately drawn to scale. The molar ratios of PAD-SC:PAD-ST:ST-PAD-ST were 2:0:1 (H1), 4:2:1 (H2), 6:4:1 (H3), 1:1:0 (H4). For each assembly, one repeating unit within the gel is highlighted. (b) Denaturing $16 \%$ SDS-PAGE analysis of the various types of hydrogels ( $\mathrm{H} 1-\mathrm{H} 4)$. The assembly reaction was carried out for $30 \mathrm{~min}$ at $30^{\circ} \mathrm{C}$ and $1000 \mathrm{rpm}$ and was quenched by the addition of $4 \times$ SDS-PAGE loading dye and incubation at $95^{\circ} \mathrm{C}$ for $10 \mathrm{~min}$.

To evaluate the ST/SC coupling in these systems, the formation of the covalent isopeptide bond was monitored by SDS-PAGE analysis (Figure 3b). Indeed, the expected dimeric and trimeric PAD conjugates were clearly formed. As expected, the ST-PAD-ST variant, which contains two crosslinking handles, formed trimeric conjugates with monomers of the PAD-SC, as indicated by the dominant band of approximately $87 \mathrm{kDa}$ in lane $\mathrm{H} 1$. This result also proves the accessibility of both the N- as well as C-terminal SpyTag peptide in the ST-PAD-ST construct. In contrast, no higher conjugates were observed when single-tagged PAD-ST was used (lane H4).

Microrheological experiments were carried out to confirm the polymeric nature of the hydrogels and to quantitatively determine the degree of crosslinking in the various $\mathrm{H} 1-\mathrm{H} 4$ materials in order to identify the most stable gel for the subsequent flow experiments (Figure 4). All hydrogels were obtained as monolithic, elastic materials with rheological properties comparable to hydrogels prepared from different enzymes, as reported previously by our group [44,46]. Figure 4a shows the variation of mean square-displacements (MSDs) as a function of lag time for polystyrene particles with a diameter of $200 \mathrm{~nm}$ dispersed in the hydrogel H1. All MSDs are almost independent of time (slope $\approx 0$ ) for times $\tau<1 \mathrm{~s}$ with a narrow distribution of absolute values characterized by a non-Gaussian parameter $\alpha \approx 1$. This result is consistent with an elastic trapping of tracer particles in a homogeneous gel-like network. Similar results were obtained for all hydrogels investigated. The calculation of the elastic shear modulus $G_{0}$ using the relation $G_{0}=2 k_{\mathrm{B}} T / 3 \pi \alpha \Delta r^{2}$ where $k_{B}$ is the Boltzmann constant, $T$ the temperature, $\alpha$ the tracer particle radius and $\Delta r^{2}$ the time-independent average MSD exhibits a gradual decrease of $G_{0}$ from $33 \pm 5$ via $17 \pm 2$ and $16 \pm 1$ to $11 \pm 1$ Pa for H1, H2, H3 and H4, respectively. The higher elasticity obtained for $\mathrm{H} 1$ is presumably due to the fact that $\mathrm{H} 1$ contains the highest amount of divalent ST-PAD-ST whereas H4 is built solely from fusion proteins with only two binding valences, which suggests in the latter case the occurrence of much less crosslinking events. Finally, we directly determined the mesh size $\xi$ of the network according to the classical theory of rubber elasticity with $G_{0}=\frac{k_{B} T}{\xi^{3}}$ and we found a significant $\xi$ increase from $50 \pm 3 \mathrm{~nm}$ for H1 to $73 \pm 3 \mathrm{~nm}$ for H4 (Figure $4 \mathrm{~b}$ ), 
which corresponds with a decrease of the crosslinking proportion. Hence, the significantly larger elasticity and smaller mesh size of $\mathrm{H} 1$ reflects the greater connectivity that originates from the higher amounts of ST-PAD-ST providing four valences as branching points. Hydrogel H1, as the most tightly connected material, was selected as the formulation for the subsequent experiments in the flow reactor. Altogether, this study also illustrates that the rheological properties of the novel all-enzyme hydrogels can be rationally modulated by adjusting the stoichiometric crosslinker ratio.

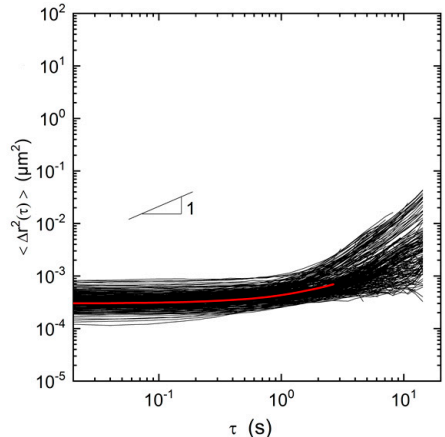

(a)

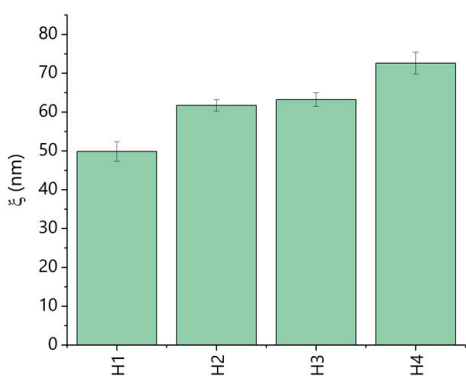

(b)

Figure 4. Multiple particle tracking (MPT) microrheology analysis of local viscoelastic properties of different types of PAD hydrogels (H1-H4, specified in Figure 3). (a) Mean square displacements (MSDs) (black curves) of individual fluorescent marker beads of diameter $200 \mathrm{~nm}$ dispersed in the hydrogel H1. The red curve is the ensemble-average MSD. (b) Comparison between mesh size values $\xi$ as deduced from MPT experiments for the different hydrogels. All experiments were carried out in duplicates. Note that the experimentally determined mesh correlate with the fraction of crosslinking proposed for hydrogel samples $\mathrm{H} 1-\mathrm{H} 4$.

To shed light on the assembly kinetics, the ST/SC-mediated gelation of PAD-SC with the double-tagged ST-PAD-ST was further investigated by SDS-PAGE analysis (Figure 5). The results indicated that the coupling reaction is almost completed within the first few minutes after mixing. In contrast, no polymerization occurred even after prolonged incubation times in control reactions with variants lacking complementary binding sites (lane 10 in Figure 5). Hence, these results clearly confirm and emphasize the excellent coupling capabilities of the PAD variants, thereby emphasizing the specificity and high reaction rates of the ST/SC system [47].

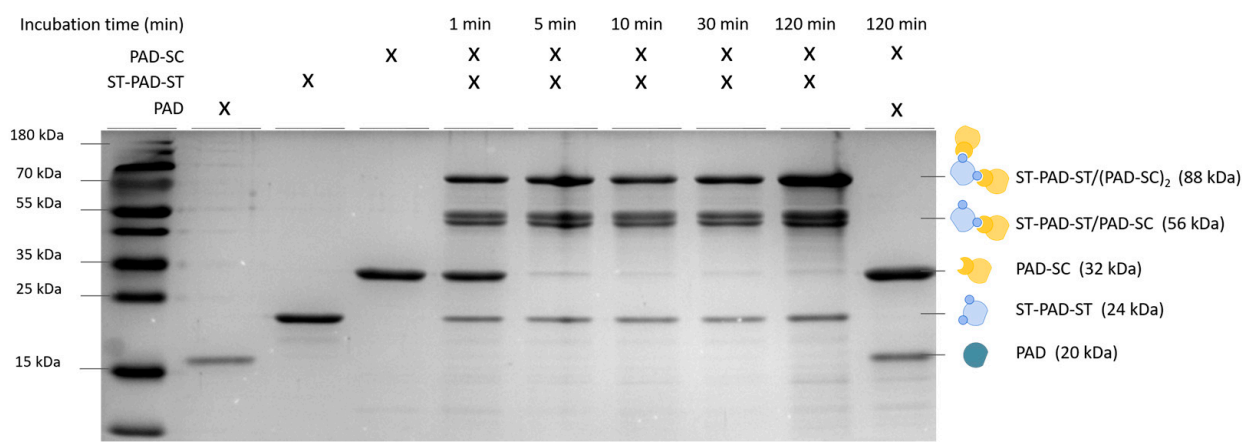

Figure 5. Kinetic analysis of the ST/SC-conjugation of ST-PAD-ST and PAD-SC analyzed by coomassie stained 16\% SDS-PAGE. Stoichiometric amounts (30 pmol) of both enzymes were incubated for up to $2 \mathrm{~h}$ at $30^{\circ} \mathrm{C}$. The reaction was stopped by the addition of $4 \times$ SDS-PAGE loading buffer and heat inactivation, which leads to denaturation of non-covalent protein interactions. As expected, the covalent bond between ST-PAD-ST and PAD-SC is rapidly formed upon mixing, leading to the formation of dimeric and trimeric conjugates with sizes of $55 \mathrm{kDa}$ and $87 \mathrm{kDa}$, respectively. Note that PAD-SC (32 kDa) does not react with PAD (20 kDa) even after a prolonged incubation of $120 \mathrm{~min}$ (lane 10). 
We then used the polymerization of the PAD variants to produce biocatalytic hydrogels that were mounted into miniaturized flow reactors in order to facilitate the continuous synthesis of $p$-hydroxystyrene (Figure 6). To this end, syringes containing a $5 \mathrm{mM}$ solution of $p$-coumaric acid were connected to PDMS microreactors loaded with hydrogel $\mathrm{H} 1$ and the substrate solution was perfused at a flow rate of $10 \mu \mathrm{L} \cdot \mathrm{min}^{-1}$ with automated sampling of the outflow (Figure 6a). The microreactor architecture featured a reactor volume of $150 \mu \mathrm{L}$ with dimensions of $3 \times 1 \times 54 \mathrm{~mm}$. The PAD-based all-enzyme hydrogel showed a stable and almost complete conversion for time periods of $>10 \mathrm{~h}$ (Figure $6 \mathrm{~b}$ ) with only traces of the substrate remaining in the product samples, as determined by reverse phase HPLC (inset in Figure 6b). The high and constant conversion rates even after longer runtimes indicate that no significant enzyme leaching takes place, which would otherwise lead to a constant decline in turnover. Without further optimization, a typical space time yield (STY) of $57.7 \mathrm{~g} \cdot(\mathrm{d} \cdot \mathrm{L})^{-1}$ with conversions $\geq 98 \%$ was obtained. Hence, this initial proof-of-concept study clearly indicated that the novel PAD-based all-enzyme hydrogels hold a great potential for further optimization and application in biocatalysis.

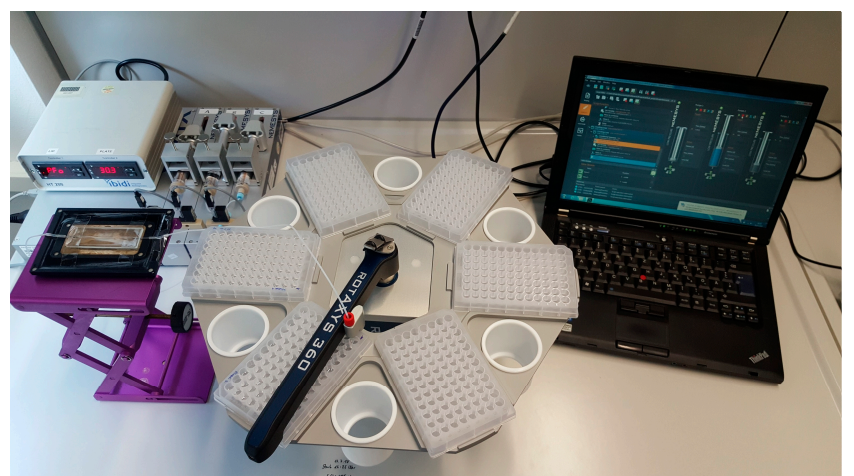

(a)

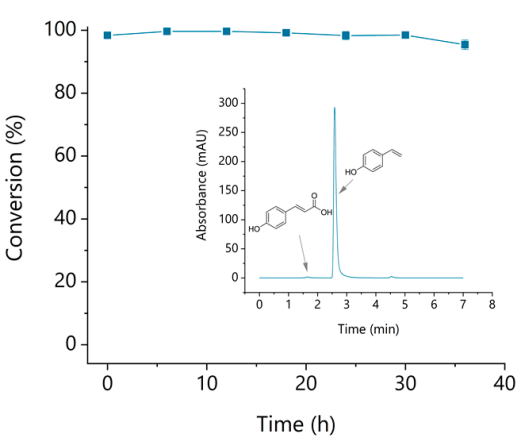

(b)

Figure 6. Continuous flow, biocatalytic production of p-hydroxystyrene using PAD hydrogel-loaded microreactors. (a) Microfluidic set-up used in this study. (b) Time dependent synthesis of $p$-hydroxystyrene, determined from the outflow of the enzyme-loaded reactor that was perfused with $5 \mathrm{mM}$ substrate at a flowrate of $10 \mu \mathrm{L} / \mathrm{min}$ at $25^{\circ} \mathrm{C}$. The PDMS reactor had a total volume of $150 \mu \mathrm{L}$. The shown data was determined by reverse phase HPLC (inset) from two separate experiments.

\section{Conclusions}

In conclusion, we herein describe a novel material, a self-assembling all-enzyme decarboxylase hydrogel, that was used for biocatalytic flow synthesis of $p$-hydroxystyrene, which in turn can be used for the synthesis of fine chemicals and pharmaceuticals. We here demonstrate for the first time, that a phenolic acid decarboxylase from Enterobacter sp. can be genetically fused with either ST or SC polypeptide domains without compromising the enzyme's catalytic performance. We also demonstrate that the biocatalytic hydrogels can be adjusted in terms of their rheological properties and mesh size by simply varying the stoichiometric molar ratio of the interconnecting fusion partners. Further in-depth studies of the modular composition and the resulting changes in polymer properties will be used to optimize the biocatalytic performance and compare it with other immobilization methods. The proof-of-concept results presented here already clearly show that the PAD-based hydrogels are excellently suited for applications in flow biocatalysis. This enabled us to generate a conversion $\geq 98 \%$ in a straight channel reactor with a volume of $150 \mu \mathrm{L}$ and a space-time yield of $57.7 \mathrm{~g} \cdot(\mathrm{d} \cdot \mathrm{L})^{-1}$. Therefore, our study does not only expand the scope of all-enzyme hydrogels by adding a new enzyme with high application relevance to the toolbox. The present work also suggests that our approach holds great potential for the establishment of advanced microfluidic manufacturing processes that include numbering up of chips to improve productivity [46] or the implementation of biocatalytic and chemoenzymatic cascades in machine-assisted compartmentalized production processes [32]. 
Author Contributions: Conceptualization, E.M., S.G., C.M.N. and K.S.R.; Data curation, E.M., S.G., C.O., C.M.N and K.S.R.; Formal analysis, E.M.; Funding acquisition, S.G., P.B., C.M.N. and K.S.R.; Investigation, E.M., S.G., and C.O.; Methodology, E.M., S.G., P.B. and C.O.; Project administration, C.M.N. and K.S.R.; Resources, N.W., C.M.N. and K.S.R.; Software, E.M., C.O. and N.W.; Supervision, C.M.N. and K.S.R.; Validation, E.M., C.O., C.M.N. and K.S.R.; Visualization, E.M.; Writing—original draft, E.M.; Writing—review \& editing, S.G., P.B., C.O., C.M.N. and K.S.R.

Funding: This work was supported by the Helmholtz programme "Bio-Interfaces in Technology and Medicine". Sabrina Gallus and Patrick Bitterwolf thank "Fonds der Chemischen Industrie (FCI)" for a Kekulé fellowship.

Acknowledgments: We thank Martin Peng for providing the expression plasmid for PAD-His and Anke Dech and Miriam Wolters for experimental help.

Conflicts of Interest: The authors declare no conflict of interest.

\section{References}

1. Dawes, G.J.S.; Scott, E.L.; Le Notre, J.; Sanders, J.P.M.; Bitter, J.H. Deoxygenation of biobased molecules by decarboxylation and decarbonylation-A review on the role of heterogeneous, homogeneous and bio-catalysis. Green Chem. 2015, 17, 3231-3250. [CrossRef]

2. Cadot, S.; Rameau, N.; Mangematin, S.; Pinel, C.; Djakovitch, L. Preparation of functional styrenes from biosourced carboxylic acids by copper catalyzed decarboxylation in PEG. Green Chem. 2014, 16, 3089-3097. [CrossRef]

3. Robinson, A.M.; Hensley, J.E.; Medlin, J.W. Bifunctional Catalysts for Upgrading of Biomass-Derived Oxygenates: A Review. ACS Catal. 2016, 6, 5026-5043. [CrossRef]

4. Gunawardena, D.A.; Fernando, S.D. Methods and Applications of Deoxygenation for the Conversion of Biomass to Petrochemical Products. In Biomass Now-Cultivation and Utilization; Matovic, M.D., Ed.; InTech: Croatia, Yugoslavia, 2013. [CrossRef]

5. Xiao, X.; Bergstrom, H.; Saenger, R.; Johnson, B.; Sun, R.C.; Peterson, A. The role of oxygen vacancies in biomass deoxygenation by reducible zinc/zinc oxide catalysts. Catal. Sci. Technol. 2018, 8, 1819-1827. [CrossRef]

6. Ni, J.; Wu, Y.T.; Tao, F.; Peng, Y.; Xu, P. A Coenzyme-Free Biocatalyst for the Value-Added Utilization of Lignin-Derived Aromatics. J. Am. Chem. Soc. 2018, 140, 16001-16005. [CrossRef] [PubMed]

7. Leisch, H.; Grosse, S.; Morley, K.; Abokitse, K.; Perrin, F.; Denault, J.; Lau, P.C.K. Chemicals from agricultural biomass: Chemoenzymatic approach for production of vinylphenols and polyvinylphenols from phenolic acids. Green Process. Synth. 2013, 2, 7-17. [CrossRef]

8. Morley, K.L.; Grosse, S.; Leisch, H.; Lau, P.C.K. Antioxidant canolol production from a renewable feedstock via an engineered decarboxylase. Green Chem. 2013, 15, 3312-3317. [CrossRef]

9. Zakzeski, J.; Bruijnincx, P.C.; Jongerius, A.L.; Weckhuysen, B.M. The catalytic valorization of lignin for the production of renewable chemicals. Chem. Rev. 2010, 110, 3552-3599. [CrossRef]

10. Liu, D.J.; Sun, J.; Simmons, B.A.; Singh, S. N-Heterocyclic Carbene Promoted Decarboxylation of Lignin-Derived Aromatic Acids. ACS Sustain. Chem. Eng. 2018, 6, 7232-7238. [CrossRef]

11. Tinikul, R.; Chenprakhon, P.; Maenpuen, S.; Chaiyen, P. Biotransformation of Plant-Derived Phenolic Acids. Biotechnol. J. 2018, 13, e1700632. [CrossRef]

12. Liu, J.; Liu, Q.; Yi, H.; Qin, C.; Bai, R.; Qi, X.; Lan, Y.; Lei, A. Visible-light-mediated decarboxylation/oxidative amidation of alpha-keto acids with amines under mild reaction conditions using $\mathrm{O}(2)$. Angew. Chem. Int. Ed. Engl. 2014, 53, 502-506. [CrossRef] [PubMed]

13. Aleku, G.A.; Prause, C.; Bradshaw-Allen, R.T.; Plasch, K.; Glueck, S.M.; Bailey, S.S.; Payne, K.A.P.; Parker, D.A.; Faber, K.; Leys, D. Terminal Alkenes from Acrylic Acid Derivatives via Non-Oxidative Enzymatic Decarboxylation by Ferulic Acid Decarboxylases. ChemCatChem 2018, 10, 3736-3745. [CrossRef] [PubMed]

14. Payer, S.E.; Faber, K.; Glueck, S.M. Non-Oxidative Enzymatic (De)Carboxylation of (Hetero)Aromatics and Acrylic Acid Derivatives. Adv. Synth Catal. 2019, 361, 2402-2420. [CrossRef] [PubMed]

15. Rosazza, J.P.; Huang, Z.; Dostal, L.; Volm, T.; Rousseau, B. Review: Biocatalytic transformations of ferulic acid: An abundant aromatic natural product. J. Ind. Microbiol. 1995, 15, 457-471. [CrossRef]

16. Ferré-Filmon, K.; Delaude, L.; Demonceau, A.; Noels, A.F. Catalytic methods for the synthesis of stilbenes with an emphasis on their phytoalexins. Coordin. Chem. Rev. 2004, 248, 2323-2336. [CrossRef] 
17. Savio, M.; Ferraro, D.; Maccario, C.; Vaccarone, R.; Jensen, L.D.; Corana, F.; Mannucci, B.; Bianchi, L.; Cao, Y.; Stivala, L.A. Resveratrol analogue 4,4'-dihydroxy-trans-stilbene potently inhibits cancer invasion and metastasis. Sci. Rep. 2016, 6, 19973. [CrossRef]

18. Nasrullah, J.M.; Raja, S.; Vijayakumaran, K.; Dhamodharan, R. A practical route for the preparation of poly(4-hydroxystyrene), a useful photoresist material. J. Polym. Sci. Part A Polym. Chem. 2000, 38, 453-461. [CrossRef]

19. Landete, J.M.; Rodriguez, H.; Curiel, J.A.; de las Rivas, B.; Mancheno, J.M.; Munoz, R. Gene cloning, expression, and characterization of phenolic acid decarboxylase from Lactobacillus brevis RM84. J. Ind. Microbiol. Biotechnol. 2010, 37, 617-624. [CrossRef]

20. Rodriguez, H.; Landete, J.M.; Curiel, J.A.; de Las Rivas, B.; Mancheno, J.M.; Munoz, R. Characterization of the p-coumaric acid decarboxylase from Lactobacillus plantarum CECT 748(T). J. Agric. Food Chem. 2008, 56, 3068-3072. [CrossRef]

21. Sheng, X.; Lind, M.E.; Himo, F. Theoretical study of the reaction mechanism of phenolic acid decarboxylase. FEBS J. 2015, 282, 4703-4713. [CrossRef]

22. Rodriguez, H.; Angulo, I.; de Las Rivas, B.; Campillo, N.; Paez, J.A.; Munoz, R.; Mancheno, J.M. p-Coumaric acid decarboxylase from Lactobacillus plantarum: Structural insights into the active site and decarboxylation catalytic mechanism. Proteins 2010, 78, 1662-1676. [CrossRef] [PubMed]

23. Gao, S.; Yu, H.N.; Wu, Y.F.; Liu, X.Y.; Cheng, A.X.; Lou, H.X. Cloning and functional characterization of a phenolic acid decarboxylase from the liverwort Conocephalum japonicum. Biochem. Biophys. Res. Commun. 2016, 481, 239-244. [CrossRef] [PubMed]

24. Sheng, X.; Himo, F. Theoretical Study of Enzyme Promiscuity: Mechanisms of Hydration and Carboxylation Activities of Phenolic Acid Decarboxylase. ACS Catal. 2017, 7, 1733-1741. [CrossRef]

25. Gu, W.; Yang, J.; Lou, Z.; Liang, L.; Sun, Y.; Huang, J.; Li, X.; Cao, Y.; Meng, Z.; Zhang, K.Q. Structural basis of enzymatic activity for the ferulic acid decarboxylase (FADase) from Enterobacter sp. Px6-4. PLoS ONE 2011, 6, e16262. [CrossRef] [PubMed]

26. Schweiger, A.K.; Rios-Lombardia, N.; Winkler, C.K.; Schmidt, S.; Moris, F.; Kroutil, W.; Gonzalez-Sabin, J.; Kourist, R. Using Deep Eutectic Solvents to Overcome Limited Substrate Solubility in the Enzymatic Decarboxylation of Bio-Based Phenolic Acids. ACS Sustain. Chem. Eng. 2019, 7, 16364-16370. [CrossRef]

27. Busto, E.; Simon, R.C.; Kroutil, W. Vinylation of Unprotected Phenols Using a Biocatalytic System. Angew. Chem. Int. Ed. Engl. 2015, 54, 10899-10902. [CrossRef] [PubMed]

28. Pesci, L.; Baydar, M.; Glueck, S.; Faber, K.; Liese, A.; Kara, S. Development and Scaling-Up of the Fragrance Compound 4-Ethylguaiacol Synthesis via a Two-Step Chemo-Enzymatic Reaction Sequence. Org. Process Res. Dev. 2017, 21, 85-93. [CrossRef]

29. Gomez Baraibar, A.; Reichert, D.; Mugge, C.; Seger, S.; Groger, H.; Kourist, R. A One-Pot Cascade Reaction Combining an Encapsulated Decarboxylase with a Metathesis Catalyst for the Synthesis of Bio-Based Antioxidants. Angew. Chem. Int. Ed. Engl. 2016, 55, 14823-14827. [CrossRef]

30. Peng, M.; Mittmann, E.; Wenger, L.; Hubbuch, J.; Engqvist, M.K.M.; Niemeyer, C.M.; Rabe, K.S. 3D-Printed phenacrylate decarboxylase flow reactors for the chemoenzymatic synthesis of 4-hydroxystilbene. Chemistry 2019. [CrossRef]

31. Lindeque, R.M.; Woodley, J.M. Reactor Selection for Effective Continuous Biocatalytic Production of Pharmaceuticals. Catalysts 2019, 9, 262. [CrossRef]

32. Rabe, K.S.; Muller, J.; Skoupi, M.; Niemeyer, C.M. Cascades in Compartments: En Route to Machine-Assisted Biotechnology. Angew. Chem. Int. Ed. Engl. 2017, 56, 13574-13589. [CrossRef] [PubMed]

33. Sheldon, R.A.; Pereira, P.C. Biocatalysis engineering: The big picture. Chem. Soc. Rev. 2017, 46, $2678-2691$. [CrossRef] [PubMed]

34. Tamborini, L.; Fernandes, P.; Paradisi, F.; Molinari, F. Flow Bioreactors as Complementary Tools for Biocatalytic Process Intensification. Trends Biotechnol. 2018, 36, 73-88. [CrossRef] [PubMed]

35. Peschke, T.; Skoupi, M.; Burgahn, T.; Gallus, S.; Ahmed, I.; Rabe, K.S.; Niemeyer, C.M. Self-Immobilizing Fusion Enzymes for Compartmentalized Biocatalysis. ACS Catal. 2017, 7, 7866-7872. [CrossRef]

36. Woodley, J.M. New frontiers in biocatalysis for sustainable synthesis. Curr. Opin. Green Sustain. Chem. 2020, 21, 22-26. [CrossRef]

37. Britton, J.; Majumdar, S.; Weiss, G.A. Continuous flow biocatalysis. Chem. Soc. Rev. 2018, 47, 5891-5918. [CrossRef] 
38. Zdarta, J.; Meyer, A.S.; Jesionowski, T.; Pinelo, M. Developments in support materials for immobilization of oxidoreductases: A comprehensive review. Adv. Colloid Interface Sci. 2018, 258, 1-20. [CrossRef]

39. Sheldon, R.A. CLEAs, Combi-CLEAs and 'Smart' Magnetic CLEAs: Biocatalysis in a Bio-Based Economy. Catalysts 2019, 9, 261. [CrossRef]

40. Cui, J.D.; Jia, S.R. Optimization protocols and improved strategies of cross-linked enzyme aggregates technology: Current development and future challenges. Crit. Rev. Biotechnol. 2015, 35, 15-28. [CrossRef]

41. Velasco-Lozano, S.; López-Gallego, F.; Mateos-Díaz, J.C.; Favela-Torres, E. Cross-linked enzyme aggregates (CLEA) in enzyme improvement-A review. Biocatalysis 2016, 1, 7626. [CrossRef]

42. Yan, E.K.; Cao, H.L.; Zhang, C.Y.; Lu, Q.Q.; Ye, Y.J.; He, J.; Huang, L.J.; Yin, D.C. Cross-linked protein crystals by glutaraldehyde and their applications. RSC Adv. 2015, 5, 26163-26174. [CrossRef]

43. Honda, T.; Miyazaki, M.; Nakamura, H.; Maeda, H. Facile preparation of an enzyme-immobilized microreactor using a cross-linking enzyme membrane on a microchannel surface. Adv. Synth. Catal. 2006, 348, 2163-2171. [CrossRef]

44. Peschke, T.; Bitterwolf, P.; Gallus, S.; Hu, Y.; Oelschlaeger, C.; Willenbacher, N.; Rabe, K.S.; Niemeyer, C.M. Self-Assembling All-Enzyme Hydrogels for Flow Biocatalysis. Angew. Chem. Int. Ed. Engl. 2018, 57, 17028-17032. [CrossRef] [PubMed]

45. Peschke, T.; Bitterwolf, P.; Hansen, S.; Gasmi, J.; Rabe, K.S.; Niemeyer, C.M. Self-Immobilizing Biocatalysts Maximize Space-Time Yields in Flow Reactors. Catalysts 2019, 9, 164. [CrossRef]

46. Bitterwolf, P.; Gallus, S.; Peschke, T.; Mittmann, E.; Oelschlaeger, C.; Willenbacher, N.; Rabe, K.S.; Niemeyer, C.M. Valency engineering of monomeric enzymes for self-assembling biocatalytic hydrogels. Chem. Sci. 2019, 10, 9752-9757. [CrossRef]

47. Zakeri, B.; Fierer, J.O.; Celik, E.; Chittock, E.C.; Schwarz-Linek, U.; Moy, V.T.; Howarth, M. Peptide tag forming a rapid covalent bond to a protein, through engineering a bacterial adhesin. Proc. Natl. Acad. Sci. USA 2012, 109, E690-E697. [CrossRef]

48. Sutherland, A.R.; Alam, M.K.; Geyer, C.R. Post-translational Assembly of Protein Parts into Complex Devices by Using SpyTag/SpyCatcher Protein Ligase. Chembiochem 2019, 20, 319-328. [CrossRef]

49. Hatlem, D.; Trunk, T.; Linke, D.; Leo, J.C. Catching a SPY: Using the SpyCatcher-SpyTag and Related Systems for Labeling and Localizing Bacterial Proteins. Int. J. Mol. Sci. 2019, 20, 2129. [CrossRef]

50. Peschke, T.; Rabe, K.S.; Niemeyer, C.M. Orthogonal Surface Tags for Whole-Cell Biocatalysis. Angezw. Chem. Int. Ed. Engl. 2017, 56, 2183-2186. [CrossRef]

51. Gu, W.; Li, X.; Huang, J.; Duan, Y.; Meng, Z.; Zhang, K.Q.; Yang, J. Cloning, sequencing, and overexpression in Escherichia coli of the Enterobacter sp. Px6-4 gene for ferulic acid decarboxylase. Appl. Microbiol. Biotechnol. 2011, 89, 1797-1805. [CrossRef]

52. Demidoff, F.C.; de Souza, F.P.; Netto, C.D. Synthesis of Stilbene-Quinone Hybrids through Heck Reactions in PEG-400. Synthesis-Stuttgart 2017, 49, 5217-5223. [CrossRef]

53. Gibson, D.G.; Young, L.; Chuang, R.Y.; Venter, J.C.; Hutchison, C.A., 3rd; Smith, H.O. Enzymatic assembly of DNA molecules up to several hundred kilobases. Nat. Methods 2009, 6, 343-345. [CrossRef] [PubMed]

54. Crocker, J.C.; Grier, D.G. Methods of digital video microscopy for colloidal studies. J. Colloid Interface Sci. 1996, 179, 298-310. [CrossRef]

55. Van Hove, L. Correlations in Space and Time and Born Approximation Scattering in Systems of Interacting Particles. Phys. Rev. 1954, 95, 249-262. [CrossRef]

56. Weeks, E.R.; Crocker, J.C.; Levitt, A.C.; Schofield, A.; Weitz, D.A. Three-dimensional direct imaging of structural relaxation near the colloidal glass transition. Science 2000, 287, 627-631. [CrossRef]

(C) 2019 by the authors. Licensee MDPI, Basel, Switzerland. This article is an open access article distributed under the terms and conditions of the Creative Commons Attribution (CC BY) license (http://creativecommons.org/licenses/by/4.0/). 